\title{
The Effect of Group Guidance Services on Student Identity
}

\author{
Bramana Nanditya Putra ${ }^{1}$, Aizamar $^{2}$, Frischa Meivilona Yendi ${ }^{3}$ \\ ${ }^{123}$ Universitas Negeri Padang
}

\section{Article Info}

\section{Article history:}

Received Nov $1^{\text {th }}, 2019$

Revised Des $4^{\text {th }}, 2019$

Accepted Jan $2^{\text {nd }}, 2020$

\section{Keyword:}

Identitas diri,

Mahasiswa

\begin{abstract}
Late adolescence, which is a transition from adolescence to adulthood, must be passed by each individual before the individual becomes a mature, responsible and creative adult. Late adolescence is also a period of transition, a period where a person is at a crossroads between what he wants and what must be done. To become adults, adolescents will go through a crisis where adolescents try to find their identity.
\end{abstract}

(C) 2019 The Authors. Published by IICET.

This is an open access article under the CC BY-NC-SA license (https://creativecommons.org/licenses/by-nc-sa/4.0

\section{Corresponding Author:}

Bramana Nanditya Putra,

Universitas Negeri Padang

Email: bramananandityaputra@gmail.com

\section{PENDAHULUAN}

Masa remaja akhir yang mana merupakan masa transisi dari masa remaja ke masa dewasa harus dilalui setiap individu sebelum individu menjadi seorang dewasa yang matang, bertanggung jawab dan kreatif. Masa remaja akhir juga merupakan masa transisi, masa dimana seseorang berada di suatu persimpangan antara apa yang diinginkan dan apa yang harus dilakukan. Untuk menjadi orang dewasa, maka remaja akan melalui masa krisis di mana remaja berusaha untuk mencari identitas diri mereka.

Remaja harus berusaha untuk menemukan jawabannya baik untuk diri sendiri maupun untuk masyarakat sekitarnya. Untuk memperoleh jawaban tentang dirinya tersebut, maka remaja harus menemukan identitas dirinya. Keadaan tersebut cukup kompleks karena melibatkan perkembangan beberapa aspek baik mental, emosional dan sosialnya (Sumiati, 2008).

Seperti yang dikatakan oleh Erikson (dalam Cintiawati, 2015) identitas diri adalah kesadaran individu untuk menempatkan diri dan memberikan arti pada dirinya dengan tepat di dalam konteks kehidupan yang akan datang menjadi sebuah kesatuan gambaran diri yang utuh dan berkesinambungan untuk menemukan jati dirinya.

Selanjutnya Grdener (dalam Amie Ristianti, 2008) juga berpendapat bahwa identitas diri adalah perasaan-perasaan yang berasal dari apa yang individu pikirkan mengenai dirinya dan apa yang individu pikir orang lain pikirkan mengenai diri individu tersebut. Masa remaja merupakan masa dimana individu mulai tertarik untuk mempertanyakan kehidupannya di masa lalu, apa yang sebenarnya dilakukan sekarang, apa peranannya, ingin menjadi seperti apa, dan apa yang ingin diraih di masa yang akan datang. Pada masa remaja ini juga individu mulai untuk mengembangkan konsep dan ide-ide yang berbeda dari pada yang dikemukakan oleh orang tua, guru, maupun orang dewasa di sekitarnya (Fisnanin Purwanti, 2013). 
Berdasarkan penjelasan diatas, dapat dikatakan bahwa mahasiswa yaitu pada tingkatan masa remaja akhir menuju masa dewasa seharusnya sudah memiliki identitas diri yang bagus dan sesuai dengan apa yang diinginkan kedepannya nanti, hal ini dikarenakan identitas diri mempengaruhi dalam kehidupan dan aktivitas mahasiswa itu sehari-hari, baik pada saat pembelajaran maupun diluar pembelajaran. Mahasiswa yang memiliki identitas diri yang bagus tentu akan efektif dan penuh semangat dalam menjalankan kegiatannya sehari-hari, termasuk dalam hal pembelajaran dikampus. Mahasiswa itu akan mengetahui kemana arah dan tujuannya nanti setelah menyelesaikan perkuliahannya. Sementara mahasiswa yang memiliki identitas diri yang buruk, akan menghambat kegiatan efektif sehari-harinya, terutama dalam proses pembelajaran yang mana mahasiswa itu akan sering terbebani dalam menentukan arah dan tujuan setelah menyelesaikan perkuliahannya, apakah dia akan mendapatkan pekerjaan atau tidak, apakah dia bisa membahagiakan kedua orang tuanya atau tidak. Oleh sebab itu, maka mahasiswa dituntut untuk sudah memiliki identitas diri yang baik, agar proses belajarnya berjalan dengan optimal serta dapat menentukan arah dan tujuan yang ingin dicapainya, sehingga tidak memiliki rasa cemas atau beban dalam hidupnya agar dapat membahagiakan orang-orang yang disayanginya, terutama kedua orang tua.

Berdasarkan pengadministrasian Alat Ungkap Masalah (Seri UMUM) Format Perguruan Tinggi yang dilakukan pada mahasiswa S1 Jurusan Adminitrasi Pendidikan (AP) 2019 pada tanggal 18 September 2019, diketahui masalah yang paling banyak dialami oleh mahasiswa diantaranya adalah masalah mengenai identitas diri. Hal ini dapat dilihat dari 26 mahasiswa yang mengisi AUM UMUM tersebut, 17 diantaranya mengaku bermasalah pada item nomor 7 yang berbunyi "Cemas atau khawatir tentang sesuatu yang belum pasti", selanjutnya terdapat 19 orang mahasiswa yang mengaku bermasalah pada item nomor 44 yang berbunyi "Khawatir tidak mampu memenuhi tuntutan dan harapan orang tua atau keluarga", dan terdapat 15 orang mahasiswa yang mengaku bermasalah pada item no 150 yang berbunyi "Khawatir tidak menamatkan perkuliahan pada waktu yang direncanakan".

Selanjutnya, kurang bagausnya identitas diri mahasiswa AP juga dapat dilihat dari sikap dan tingkah lakunya dalam mengikuti pembelajaran dikelas. Berdasarkan pengamatan penulis selama melaksanakan praktek lapangan di Jurusan Adminitrasi Pendidikan Tahun 2019, tampak bahwa beberapa mahasiswa merasa kurang bersemangat dalam mengikuti pembelajaran di kelas, hal ini dikarenakan rasa cemas dan khawatir yang membebani terhadap jurusan yang dipilih, yang kedepannya sesuai dengan yang diharapkan apa tidak. Sebagian mahasiswa masih bingung setelah menyelesaikan perkuliahan ini akan mendapatkan pekerjaan atau tidak, yang tujuannya untuk membahagiakan orang yang disayangi, terutama kedua orang tua.

Untuk memperbaiki identitas diri mahasiswa dapat dilakukan melalui pelayanan bimbingan dan konseling. Guru BK dapat membantu memperbaiki identitas diri mahasiswa dengan memanfaatkan berbagai jenis layanan dalam bimbingan dan konseling. Salah satunya yaitu Layanan Bimbingan Kelompok. Sebab layanan bimbingan kelompok dapat memunculkan identitas diri yang baik terhadap mahasiswa. Layanan Bimbingan kelompok diduga akan menjadi primadona dari layanan-layanan yang lain karena menekankan aspek dinamika kelompok yang memiliki semangat yang tinggi, kerjasama yang lancar dan mantap, serta adanya saling mempercayai diantara anggota; anggotanya. Apabila anggota merasa bahwa kelompok itu baik maka setiap anggota kelompok akan sangat mudah mematuhi peraturan dan norma-norma yang ada (Putra, Daharnis, \& Syahniar, 2013).

Layanan bimbingan kelompok sangat berguna bagi para mahasiswa karena memberikan kesempatan untuk mengekspresikan perasaan, konflik, dan merealisasikan bahwa mereka senang berbagi perhatian dengan pemimpin kelompok dan anggota kelompok lainnya. Bimbingan kelompok merupakan salah satu layanan yang dapat memberikan kesempatan bagi anggota untuk saling menerima dan memberi ide, perasaan, dukungan maupun bantuan bagi anggota lain.

Nengsih, Firman dan Mega (2015) menjelaskan layanan bimbingan kelompok juga membantu para siswa untuk belajar tentang diri dan orang lain, serta mencoba atau mengemukakan ide-ide baru. Disamping itu, layanan bimbingan kelompok membantu terciptanya interaksi antar anggota dan pimpinan kelompok. Interaksi ini menciptakan keterbukaan, semangat untuk menjadi lebih baik, serta memberikan kesempatan kepada mahasiswa untuk saling memberi dan menerima pendapat.

Layanan bimbingan kelompok memberikan kesempatan untuk berinteraksi sehingga dapat menyampaikan apa yang ingin disampaikan dan dapat saling membantu dalam hal berbagi perhatian dan penerimaan diri dari topik yang akan dibahas.

Menurut Prayitno (2009) Bimbingan kelompok adalah layanan yang diberikan dalam suasana kelompok. Sedangkan menurut Lahmuddin (2011) layanan bimbingan kelompok merupakan layanan bimbingan yang memungkinkan sejumlah peserta didik secara bersama-sama melalui dinamika kelompok 
memperoleh berbagai bahan baru dari konselor untuk dibahas bersama-sama topik tertentu sehingga berguna untuk menunjang pemahaman dan kehidupan sehari-hari".

Berdasarkan penjelasan diatas terlihat bahwa dengan adanya bimbingan kelompok dapat menambahkan pemahaman mahasiswa mengenai identitas diri yang baik, dan bagaimana menumbuhkan identitas diri yang baik itu, sehingga mahasiswa akan terhindar dari rasa cemas dan khawatir mengenai arah dan tujuan dirinya dalam menghadapi kehidupan.

\section{METODOLOGI}

Penelitian ini merupakan penelitian kualitatif yang bersifat eksperimen, dengan subjek yaitu mahasiwa Jurusan Adminitrasi Pendidikan tahun masuk 2019 sebanyak 26 orang mahasiswa. Sedangkan teknik pengumpulan data yang digunakan adalah skala Likert untuk melihat identitas diri mahasiwa. Teknik analisis data dilakukan dengan menghimpun dan menampilkan hasil pemberian layanan Bimbingan Kelompok untuk ditarik kesimpulan mengenai identitas diri.

\section{HASIL DAN PEMBAHASAN}

\section{Kondisi Kepercayaan Diri Mahasiswa sebelum diberikan perlakuan}

Berdasarkan hasil angket yang telah di sebarkan kepada subjek penelitian yang berjumlah 26 orang mahasiswa, diperoleh hasil sebagai barikut:

Tabel 1. Gambaran identitas diri mahasiswa sebelum perlakuan

\begin{tabular}{|c|c|c|c|}
\hline Kategori & Interval & $\mathbf{F}$ & $\%$ \\
\hline Sangat Bagus & $\geq 231$ & 13 & 50 \\
\hline Bagus & $188-231$ & 13 & 50 \\
\hline Cukup & $144-187$ & 0 & 0 \\
\hline Jelek & $100-143$ & 0 & 0 \\
\hline Sangat Jelek & $\leq 99$ & 0 & 0 \\
\hline \multicolumn{2}{|c|}{ Jumlah } & 26 & 100 \\
\hline
\end{tabular}

Sesuai dengan tabel 1 diatas, tampak bahwa sebagian besar mahasiswa adminitrasi pendidikan yang identitas dirinya pada kategori bagus yaitu sebanyak 13 orang mahasiswa dengan persentase $50 \%$. Kemudian diikuti dengan 13 orang mahasiswa yang identitas diri nya sangat bagus dengan persentase $50 \%$.

Oleh karena itu, dengan adanya mahasiswa yang identitas dirinya pada kategori bagus pada mahasiswa adminitrasi pendidikan perlu diberikan layanan Bimbingan Kelompok untuk membuat identitas seluruh mahasiswa Adminitrasi Pendidikan menjadi sangat bagus semua dan siap untuk menjalani perkuliahannya dengan penuh semangat dan optimis

Kondisi Kepercayaan Diri Mahasiswa setelah diberikan perlakuan

Berdasarkan hasil angket yang telah di sebarkan kepada subjek penelitian yang berjumlah 26 orang mahasiswa, diperoleh hasil sebagai barikut:

Tabel 2. Gambaran identitas diri mahasiswa setelah perlakuan

\begin{tabular}{|c|c|c|c|}
\hline Kategori & Interval & $\mathbf{F}$ & $\%$ \\
\hline Sangat Bagus & $\geq 231$ & 18 & 69 \\
\hline Bagus & $188-231$ & 8 & 31 \\
\hline Cukup & $144-187$ & 0 & 0 \\
\hline Jelek & $100-143$ & 0 & 0 \\
\hline Sangat Jelek & $\leq 99$ & 0 & 0 \\
\hline \multicolumn{2}{|c|}{ Jumlah } & 26 & 100 \\
\hline
\end{tabular}


Berdasarkan tabel 2 diatas, tampak bahwa mahasiswa yang identitas dirinya pada kategori bagus yaitu sebanyak 8 orang mahasiswa dengan persentase $31 \%$. Kemudian diikuti dengan 18 orang mahasiswa yang identitas diri nya sangat bagus dengan persentase $69 \%$.

Oleh karena itu, dapat disimpulkan bahwa adanya perubahan yang terjadi mengenai identitas diri mahasiswa yang meningkat dari bagus menjadi sangat bagus sebanyak $20 \%$. Jadi, Layanan Bimbingan kelompok dapat membantu mahasiswa dalam meningkatkan identitas dirinya menjadi sangat bagus.

\section{KESIMPULAN}

Mahasiswa Jurusan Adminitrasi Pendidkan tahun masuk 2019 sebagian besar masih belum memiliki identitas diri yang sangat bagus, sehingga mereka masih memiliki rasa cemas dan khawatir serta kurang semangat dalam menjalani kehidupannya, terutama dalam proses pembelajaran. Hal-hal yang mempengaruhi identitas diri mahasiswa yang belum sangat bagus adalah rasa cemas dan khawatir kedepannya setelah menyelesaikan perkuliahan tidak mendapatkan pekerjaan dan membahagiakan orang-orang yang disayanginya, terutama kedua orang tua. Layanan Bimbingan kelompok dapat membantu mahasiswa dalam meningkatkan identitas dirinya menjadi sangat bagus.

\section{SARAN}

Berdasarkan pembahsan hasil penelittian di atas, diharapkan mahasiswa dapat membangun dan menciptakan persepsi positif tentang diri mereka, serta keyakinan yang kuat dalam diri mereka. Selain itu, mahasiswa juga dituntut perlu memiliki identitas diri yang sangat bagus untuk membuat kegiatan mereka sehari-hari terutama dalam proses belajar menjadi serius dan semangat demi menggapai cita-cita yang diharapkan dan dapat membahagiakan kedua orang tua.

\section{KEPUSTAKAAN}

Amie Ristianti. (2008). Hubungan Antara Dukungan Sosial Teman Sebaya dengan Identitas Diri Pada Remaja di SMA Pusaka 1 Jakarta. Amie. Evolution, 000, 1-14.

Cintiawati, N. (2015). IDENTITAS DIRI PADA REMAJA DARI KELUARGA BERBEDA AGAMA (STUDI FENOMENOLOGI PADA REMAJA DARI KELUARGA DENGAN LATAR BELAKANG AGAMA YANG BERBEDA), $\operatorname{XII}(2), 86-93$.

Firman, F. (2018). Efektivitas Pelaksanaan Layanan Bimbingan Kelompok Dengan Menggunakan Media Audio Visual Untuk Meningkatkan Konsep Diri Siswa. Diakses pada laman https://www.researchgate. net/profile/firman_firman11/publication/328554002_efektivitas_pelaksanaan_layanan_bimbingan_kelompok_deng an_menggunakan_media_audio_visual_untuk_meningkatkan_konsep_diri_siswa/links/5bdc0eb6299bf1124fb492bc/ efektivitas-pelaksanaan-layanan-bimbingan-kelompok-dengan-menggunakan-media-audio-visual-untukmeningkatkan-konsep-diri-siswa.pdf

Fisnanin Purwanti. (2013). IDENTITAS DIRI REMAJA PADA SISWA KELAS XI SMA NEGERI 2 PEMALANG DITINJAU DARI JENIS KELAMIN. Semarang.

Lahmuddin. (2011). Landasan Formal Bimbingan Konseling Di Indonesia. Bandung: Cipta Pustaka Media Perintis.

Nengsih, N., Firman, F., \& Iswari, M. (2015). Pengaruh Layanan Bimbingan Kelompok Terhadap Perencanaan Arah Karier Siswa SMA Pembangunan Laboratorium Universitas Negeri Padang. Konselor, 4(3), 136-146.

Prayitno dan Erman Amti. (2009). Dasar-dasar Bimbingan dan Konseling. Jakarta: Rineka Cipta.

Sumiati, E. (2008). IDENTITAS DIRI REMAJA PADA SISWA SMA KARTIKA I-2 MEDAN, 30-34. 